\title{
Ethical Considerations in Exploiting, Culturing and Killing Fish towards Animal Rights in Islam
}

\author{
M.M Rahman ${ }^{1}$, Kamaruzzaman Yunus ${ }^{1}$, Raslan Alenezi ${ }^{2}$ \\ ${ }^{1}$ Department of Marine Science, Kulliyyah of Science, International Islamic University Malaysia ,Kuantan, \\ Pahang, Malaysia \\ ${ }^{2}$ College of Technological Studies, Chemical Engineering Department, P.O. Box 42325, Shuwaikh 70654, \\ Kuwait
}

\begin{abstract}
Human show cruelty to fish during exploiting, culturing, killing, experimentation and amusement. Presently, overexploitation of marine fishes is a serious problem worldwide. More than $50 \%$ of total fish production is now raised in aquafarms where many fish suffer from parasitic infections, diseases, and debilitating injuries in culture systems. Every year, millions of fish are caught in nets and on hooks. Many of them are tortured just for sports. Fishes are also regularly used for scientific experiments. Many of them are killed by unethical ways. Among all animals, human is the main culprits in causing harms to animals including fishes by damaging their ecosystems. To secure animal rights, modern bio-ethics started to be developed in the last century. The principle of modern bio-ethics is very similar to the principle of Islamic bio-ethics. Therefore, modern bio-ethics might be guided by Islamic bio-ethics, which was well established in the $7^{\text {th }}$ century. According to Islam, God gave the human being responsibility to look after animals, to protect them, and not to abuse or threaten them. Human is not permitted to kill animals just for sports or amusements. God created the universe in a perfect balance and human should not disturb this. Therefore, human may exploit and culture food (fish and other organisms) and ornaments without destroying aquatic ecosystems. Islam prescribes a set of rules to treat animals with the utmost kindness and compassion. However, Islamic direction can be integrated with science to ensure minimum stress, pain and suffering when killing animals including fishes.
\end{abstract}

KEYWORDS: Ethical Issue, Fishing, Aquaculture, Fish Killing, Ecosystem

\section{INTRODUCTION}

As a highly accessible food source, fish are widely consumed by the human. In 2012, the global per capita consumption was more than $19 \mathrm{~kg}$, which contributed to more than $17 \%$ percent of the global population animal protein intake. ${ }^{1}$ Fish protein provides essential amino acids while fish fat is rich in polyunsaturated fatty acids (PUFA), which have beneficial effects on many diseases such as heart disease, diabetes, cancer and inflammatory disease. ${ }^{2}$ PUFA is important for maintaining the integrity of membrane of all living cells by making prostaglandins, which regulate many body processes such as inflammation and blood clotting. ${ }^{3}$ Some marine fish proteins protect against the development of dietinduced insulin resistance. ${ }^{4}$ Furthermore, eating fish during pregnancy may help to reduce the risk of premature birth. ${ }^{5}$

Fish are supplied either by exploiting them from seas, rivers and lakes or by culturing them in ponds,

Corresponding author:

Associate Prof. Dr. Mohammad Mustafizur Rahman, Department of Marine Science,

Faculty (Kulliyyah) of Science,

International Islamic University Malaysia,

Jalan Sultan Ahmad Shah,

25200 Kuantan,

Pahang, Malaysia

Email:mustafiz@iium.edu.my tanks and cages. It has been observed that many countries in the world have over exploited marine fishes and other marine resources to meet up the fish demand for growing population. ${ }^{6}$ Aquaculture is another type of fish production method which is currently expanding very rapidly to bridge the gap between supply and demand. ${ }^{7}$ Presently, aquaculture is contributing nearly $50 \%$ of the global fish production. ${ }^{1}$ Both overfishing and fish culture are affecting aquatic ecosystems including biodiversity and causing tremendous threats directly or indirectly to aquatic animals. ${ }^{8,9}$ However, animal rights are usually violated in various steps of exploitation and aquaculture of fishes. ${ }^{10,11}$ Angling is another type of fishing activity, which is widely used for human amusements. It causes enormous stress, pain and physical injuries to the fish. ${ }^{12}$ Fish are also used as the experimental animal in various scientific researches including medical researches. ${ }^{13}$ For example, zebra fish (Danio rerio) is used for medical research since its genetic structure is similar to that of a human. ${ }^{13}$ However, animal rights are usually violated when fish are used as the experimental animal.

Animal rights movement can play a significant role to protect welfare and rights of aquatic animals including fish. United Nations adopted global human rights to protect and promote human rights throughout the world. Unfortunately, there is no universal declaration of non-human animal rights 
particularly the rights of aquatic animals. Realizing rapid changes of aquatic biodiversity and ecosystems, some countries started to adopt ethical guidelines to protect aquatic animals and ecosystems. ${ }^{10}$ However, Islam as a religion has a strong philosophical root and practical implications on animal rights ${ }^{14}$. Therefore, Islamic ethical guidelines can make both an ethical and educational contribution to protect aquatic animals and ecosystems globally. In this paper, the major ethical issues in exploiting, culturing and killing fish are identified using published literature. This paper also discusses Islamic guidelines of exploiting, culturing and killing fish to protect aquatic ecosystems and rights of aquatic animals.

\section{Biodiversity Issue}

Human has been exploiting fish in the lakes, river and sea since time imme-morial. This was never a problem due to abundant resources. Fishing became very effective in the early nineteenth century when this sector was mechanized and industrialized. ${ }^{15}$ Increasing demand for fish for growing population and mechanized fishing have caused a significant decrease in fish populations in many lakes, rivers and seas. ${ }^{15}$ This resulted in depletion of many important fish stocks in many aquatic habitats in the world. For example, the production of some fish species such as yellowstripe scad (Selaroides leptolepis) and other carangid fishes are decreasing very rapidly in Malaysian water (Figure 1), where the production of yellowstripe scad decreased by more than $60 \%$ in last 13 years. ${ }^{16}$ A similar scenario was also observed in the case of other carangid fishes. ${ }^{16}$ Presently, overexploitation of marine fishes is a serious issue worldwide. According to FAO (2014), 61\% of the world's commercial fish stocks are currently reported as fully exploited and 29\% are overexploited. ${ }^{1}$ Overexploitation together with unsustainable exploitation are leading many fish stocks to the point of collapse. Some fish stock like Atlantic bluefin tuna (Thunnus thynnus), have declined to the point of threatened fish species.17 However, overexploitation not only collapses fish stocks but it also destroys aquatic ecosystems as it hampers feeding relationships among fish species. For example, overexploitation of a large carnivorous fish stock can result in a large increase in the food for small herbivorous fish and copepods, with consequences for bottom-dwelling fish. ${ }^{18}$ Overexploitation not only affects the habitats and community in the water column but it also affects the benthic habits and community structure. ${ }^{19,20}$ However, overexploitation of one fish species leads to dramatic changes in the structure and function of the marine ecosystem. ${ }^{21}$ Thus, marine biodiversity is greatly affected by overfishing.

Aquaculture is another human activity that is increasingly affecting the biodiversity of fish and indirectly biodiversity of other marine organisms. Aquaculture of high-value carnivorous fish is rapidly expanding to bridge the gap between supply and demand. ${ }^{7,22}$ Presently, more than 150 fish species are cultured in a variety of aquaculture production systems such as ponds, tanks, raceways, and cages. ${ }^{1}$ Among these aquaculture production systems, the majority of the production comes from freshwater ponds and marine fish cages in which various carnivorous fishes are the main culture species. A lot of fish are destroyed to extract fish oil, which is the main fat source of fish feed. Similarly, fish meal is the prime protein source in the feed of carnivorous fish, which consume considerably more

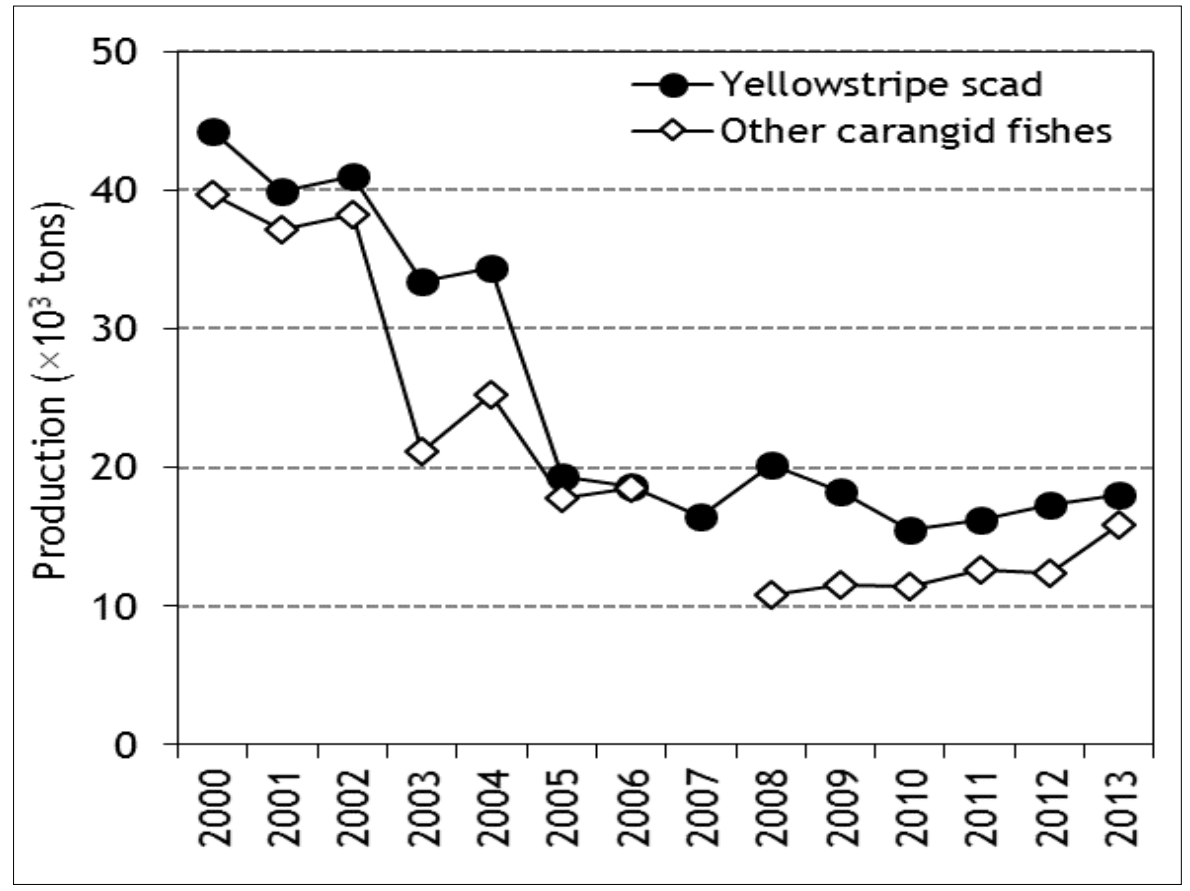

Figure 1: Status of yellowtripe scad and other carangid production in Malaysia (data from FAO). ${ }^{16}$ 
fish protein than they produce. ${ }^{23,24,25}$ According to Naylor et al. (2000), culturing of carnivorous fish uses up to five times more fish protein than is produced. ${ }^{23}$ This indicates that up to $5 \mathrm{~kg}$ of marine fish is destroyed to produce $1 \mathrm{~kg}$ of carnivorous fish. Therefore, some marine fish stocks may be decreasing with the rapid expansion of carnivorous fish farming. According to FAO (2012), around 7\% of marine fish stocks have been totally depleted due to over fishing. ${ }^{26}$

Genetic modification and hybridization are frequently used in aquaculture to increase growth, survival and disease resistance. ${ }^{27}$ However, the ethical issue related to the genetic modification in aquaculture are the same as those for any other genetically modified agricultural crop. A major ethical question is raised when a hormone is used for gonadal maturation and artificial spawning. Presently, various hormones namely desoxycorticosteroid acetate, human chorionic gonadotropin, extract of the fish pituitary gland; are used for gonadal maturation and artificial spawning of many fishes. Both genetic modification and using hormones violates animal autonomy. However, all of these raise welfare issues and negatively influence to the animal wellbeing. Cultured fish are known to escape from aquaculture farms and interacted with local wild fish species. This changes the natural genetic architecture resulting from the transfer of genotypes among differentiated populations used in aquaculture stocks. ${ }^{27}$ Escaped exotic fish species alter biodiversity of aquatic environment through competing with native wild fishes for food and habitat. ${ }^{28}$ Selective breeding and genetic modification are very common in aquaculture species. $^{29}$ Antibiotic, antiparasitics and other chemicals flow out the fish farms and can affect wild fish and surrounding aquatic ecosystems. ${ }^{30}$ Escaped exotic fish sometimes transmits infectious diseases and causes reduction of fish and other aquatic animal population. ${ }^{30}$ All of these have negative effects on aquatic biodiversity.

\section{Pollution Issue}

Amongst the various types of aquaculture production systems namely tanks, raceways, recirculating system, earthen ponds, pens and cages; earthen pond and marine cage are widely used to fish farming. ${ }^{31,32}$ In ponds, nutrients are mostly supplied as fertilizer or as feed for fish growth, whereas in marine cages, nutrients are supplied only as feed for fish growth. ${ }^{31,32}$ As cage aquaculture is an intensive aquaculture system it mostly uses a high nitrogen content diet. One problem with this intensive aquaculture system is that only $10-30 \%$ of nitrogen and $15-40 \%$ phosphorous of fish diet is incorporated into fish biomass ${ }^{17}$. The remaining $70-90 \%$ nitrogen and $60-85 \%$ phosphorous are lost to the environment as uneaten feed and fish excreta. ${ }^{32}$ Besides nitrogen and phosphorous loading, marine fish farms discharge around $50 \%$ of the carbon in the marine environment. ${ }^{33}$ The major portion of uneaten feed and feces from these intensive fish farms are deposited on to the bottom sediments of the sea and enhance sediment metabolism, anoxia, sulphate reduction and sulphide accumulation. Such impacts can then also negatively affect benthic fauna, fish abundance, macroalgal growth and diversity, plankton communities and composition and abundance of bacteria. ${ }^{34}$ In many cases marine fish farms completely destroy sea grass meadow around the fish farm. ${ }^{31}$

The occurrence of harmful algal blooms $(\mathrm{HAB})$ is a common problem in many coastal environments. ${ }^{35}$ Every year millions of fish die in the coastal water due to $H A B$, which is mainly caused by the high load of various nutrients namely phosphorus, nitrogen, and carbon in the water. $H A B$ affects not only marine aquatic organisms but also birds and human. People often get sick by consuming shellfish containing toxins produced by these harmful algae. Marine pollution due to high nutrients load also causes disease outbreaks on the aquatic organisms including fish. ${ }^{31,32}$ Various pollutants from fish farms have significant effects on all other environmental factors that severely influence growth, survival, spawning and well-being of aquatic animals. ${ }^{36}$ Pollutant or chemical resistant strains of microorganisms raise another ethical issue of violating the environmental autonomy.

\section{Handling and Killing Issues}

Aquaculture contributes to more than half of the world fish production (Figure 2). Fish that are being cultured are given selective feed in a confined area where they have no choice on food selection and a very limited choice on free movement. ${ }^{37}$ Therefore, the fish are always in stressful conditions in most aquaculture systems. ${ }^{37}$ However, modern fish cultures violate animal rights in many stages, which include crowding, handling, food deprivation, poor water quality (low oxygen and high ammonia in the water) and diseases. Most of the aquaculture systems are intensified with high stocking densities to increase the productivity of the system. However, culturing fish at high densities affects fish welfare negatively by reducing growth, food intake, food conversion efficiency and immunity. ${ }^{38,39}$ It also increases disease susceptibility due to poor water quality. Overcrowding increases aggressive interactions and causes injuries to the eyes, tails, skin and pectoral fins of fishes. These physical injuries cause secondary infections and mortality in farmed fish. ${ }^{40,41}$

Trawling and purse seining are mostly used for commercial fishing in the sea. Fish start to panic, overrun, and swallowed by the net whilst pulling nets from water to ship. The fish become suffocated in the crush of other fish and die from circulatory failure during hauling the nets aboard. If the catch is very large, the entire stern end of the ship can be tilted down and the fish are ramped up into the boat. This is very stressful to the fish. ${ }^{42}$ Sport fishing is another important topic of ethical concern. Every year, millions of fish are caught using hook and line for human pleasure and amusements. Angling is a very cruel activity to fish as barbed hooks pierce the 


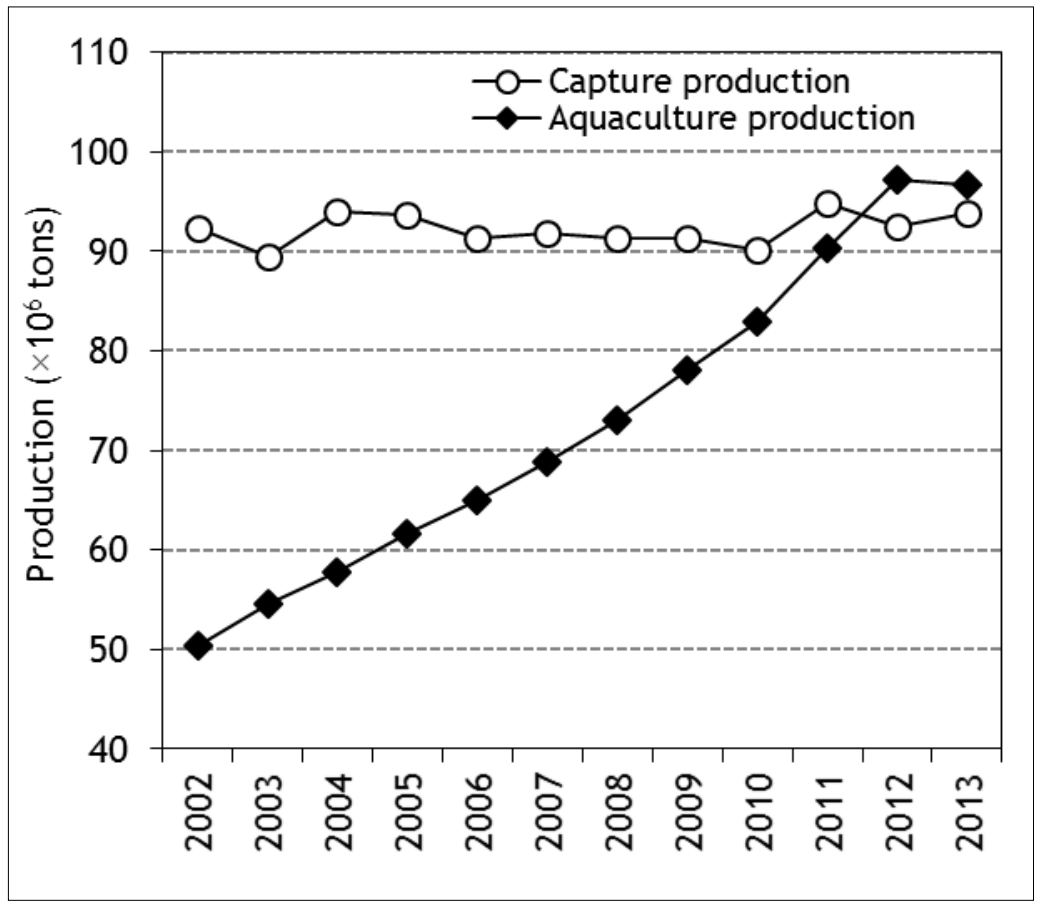

Figure 2 : Status of World's capture and aquaculture production (data from FAO). ${ }^{16}$

jaw of the fish, which are then ripped from the fish's mouth upon capture, and the fish is often left to suffocate in the open air. Fish which are caught with barbed and then returned to the water suffer very severe physiological stress. Sometimes fish swallow hooks and anglers try to retrieve the hook by shoving their fingers or pliers down the fish's throat, ripping out not just the hook but some of the fish's throat and guts as well. ${ }^{42}$ Many fish die after retrieving the hook by anglers.

Fish are increasingly used in the laboratory as an experimental animal. Fish are usually confined, abused, and killed in cruel experiments. ${ }^{43,44,45}$ During experimentation, they are provided insufficient food or toxic food or unpalatable food to conduct nutritional research. ${ }^{46,47,48}$ Fish are cultured in water containing toxic substances in chemical tolerance research. Fish are often used for marking and tagging researches. However, all of these researches using fish violate animal rights.

\section{Animal Rights in Modern Bio-Ethical and Islamic views}

The term "animal rights" has been very popular and is an issue of great debate and discussion among the scholars, social movement activists, and consumers. ${ }^{14}$ The movements for animal rights around the world have increasingly attracted both public and scholarly attention. ${ }^{14}$ Animal rights can be explained using two main approaches: i) human rights-based approach and ii) equal animal rightsbased approach. ${ }^{49}$ According to human rights-based approach, human is considered as a dictator. This approach does not treat non-human animals respectfully as ends in themselves. All non-human animals would be used as a means to human gratification. They would be treated as a means to human ends and not as an end in itself. According to equal animal rights-based approach all (human and non-human) animals have equal rights. All nonhuman animals ought to have all the same rights as humans. According to this approach there is no moral justification for using non-human animals for human purposes. This approach indicates that exploiting, culturing and killing animals for human food is a clear violation of the non-human animal rights. No matter how humanely non-human animals are treated in the process of exploiting, raising and killing them for food remains morally wrong. ${ }^{49}$

Modern bio-ethics started to consider non-human animal rights in the last century when rapid destruction of global environment and ecology due to massive industrialization was realized. ${ }^{49}$ Looking at the animal welfare code of practices adopted by various countries, it can be conclude that modern bio-ethics is still deeply rooted in human rightsbased approach. Among all animals, humans are the main culprits in causing damage ecosystems particularly terrestrial and aquatic ecosystems. ${ }^{50}$ Therefore, to safe global environment and ecology, human should consider welfare and rights of nonhuman animals and ecosystems during exploiting, raising and killing other animals. It is important to mention that the principle of modern bio-ethics is very similar to the principle of Islamic bio-ethics. As the Islamic bio-ethics was well established in the $7^{\text {th }}$ century, Islamic ethics might be the origin of modern bio-ethics, which was started to be developed in the middle of the last century. ${ }^{14}$ Unfortunately, the Muslim voice on animal rights is almost absent on a global scale although Islam has strong philosophical root and practical implications on animal rights. ${ }^{14,51}$ 
The Qur'an (the main text of Islam) along with hadith (prophetic traditions or/and sayings) are considered the sources of Islamic ethics. However, Islam allows killing of animals for food and selfdefence to prevent greater harm befalling the community. ${ }^{14}$ It does not discourage vegetarianism, reflecting that a Muslim can be a pure vegetarian as well. It neither makes vegetarianism a compulsory rule to follow nor does it encourage human beings to consume non-vegetarian food including meat. 14,52 However, the killing of non-human animals for human consumption has been the subject of debate on animal right. ${ }^{14}$ On the other hand, killing one animal by other animal for food and survival is a very common phenomenon in nature. This helps to make a balance between lower and higher trophic animals in the ecosystems. As human is a part of animal kingdom and nature, they need rights like other animals to exploit and kill animals for his own welfare. Therefore, based on human rights-based approach, killing non-human animals for human welfare is logically acceptable if it does not hamper animal sustainability and ecosystems. ${ }^{14}$

\section{Exploiting, Culturing and Killing Fish in Islam}

Modern fisheries ethics which is set by many countries are very closely related to Islamic direction. According to Islam, humankind is a superior creation of God (Allah) and all creations on the earth are human centric. ${ }^{14}$ Therefore, human can exploit, culture and kill fishes for their own welfare. According to the Qur'an, "it is He who has made the sea subject, that you may eat thereof flesh that is fresh and tender, and that may extract there from ornament to wear; and you see the ships therein that plough the waves, that you may seek (thus) of the bounty of God and that you may be grateful" (Qur'an, 16:14). This versus clearly indicates that God created sea so that humankind could find therein fresh food to eat and extract ornaments to wear. The Qu'ran also says in the famous verse which ordains the preservation of environment: "then we made you heirs in the land after them, to see how you would behave" (Qur'an, 10:14). This versus explains that humankind may exploit and culture food (fish and other organisms) and ornaments without destroying marine ecosystems. According to Islam, human should not disturb the perfect balance in the sea created by God and they should be answerable if they destroy the marine ecosystems by any activities such as exploiting and culturing fish and other organisms. Therefore, the destruction of the marine environments is considered the immoral and unethical use of natural resources. ${ }^{53}$

In Islam, there is no specific guideline about specific method of killing fish. However, Islam gives a gross direction about how to kill animals. This guideline can be applied to kill fish. According to Islam, although humankind is a superior creation of God, they do not have the right to treat animals as they would so cruel. God gave human beings the role of steward-caliph-on earth (Qur'an, 6:165). This role gives the human being responsibility to look after animals, to protect them, and not to show cruelty or threaten them. Islam says that if you have to kill non-human animals, then kill them in the best manner; if you have to slaughter, then slaughter them in the best manner.$^{54}$ However, Islam allows killing animals including fish for their own consumption in the condition of using best manner or avoiding cruelty. The term "cruelty" is usually explained by stress, pain and suffering. ${ }^{55}$ Islam suggests using a sharp knife to slaughter animals to reduce sufferings of the animals. ${ }^{14}$ However, there is no specific guideline to ensure minimum stress, pain and suffering during killing fishes and therefore, Islamic direction can be integrated with science to ensure minimum stress, pain and suffering during killing fishes. Killing fish for research is one of the most ethical concerns in animal welfare. Heat shock and electric shock are two killing methods which are widely used to kill experimental fish. ${ }^{56}$ Previously, it was assumed that these killing methods are less stressful and less painful for fish. Presently, many researchers who study animal welfare raise issues that the heat shock and electric shock can be stressful and painful. ${ }^{56}$ Presently, they recommend that fish should be unconscious before killing to confirm least stress and pain. ${ }^{56}$ Islam allows following this type of recommendation to reduce stress, pain and suffering. Cruelty to animals causes divine retribution and therefore, killing animals including fish just for fun or sport is strictly prohibited in Islam. ${ }^{14}$

\section{CONCLUSION}

Human should consider welfare and rights of other animals during exploiting, raising and killing them. To secure animal rights, modern bio-ethics started to be developed in the last century. The principle of modern bio-ethics is very similar to the principle of Islamic bio-ethics, which was well established in the $7^{\text {th }}$ century. Therefore, modern bio-ethics might be guided by Islamic bio-ethics. The Muslim's voice on animal rights is almost absent on a global scale although Islamic ethical guidelines can make both an ethical and educational contribution to protect aquatic animals and ecosystems.

\section{ACKNOWLEDGEMENT}

The authors are thankful to the Research Management Centre, International Islamic University Malaysia for providing financial support through RIGS16-309-0473 grant.

\section{REFERENCES}

1. Food and Agriculture Organization. The State of World Fisheries and Aquaculture 2014.

Rome: FAO, 2014.

2. Weber J, Bochi VC, Riberio CP, et al. Effect of different cooking methods on oxidation, proximate and fatty acid composition of silver catfish (Rhandia quelen) fillets. Food Chem 2008; 106:140-146. 
3. Jabeen F, Chaudhry AS. Chemical compositions and fatty acid profiles of three freshwater fish species. Food Chem 2011; 125:991-996.

4. Pilon G, Ruzzin J, Rioux LE, et al. Differential effects of various fish proteins in altering body weight, adiposity, inflammatory status, and insulin sensitivity in high-fat-fed rats. Metabolism 2011; 60:1122-1130.

5. Olsen SF, Secher NJ. Low consumption of seafood in early pregnancy as a risk factor for preterm delivery: Prospective cohort study. $\mathrm{Br}$ Med J 2002; 324:447-450.

6. Bolster WJ. The Mortal Sea: Fishing the Atlantic in the Age of Sail. Harvard: Harvard University Press, 2012.

7. Rahman MM. Role of common carp (Cyprinus carpio) in aquaculture production systems. Front Life Sci 2015; 8:399-410.

8. Botsford LW, Castilla JC, Peterson CH. The Management of Fisheries and Marine Ecosystems. Science 1997; 277:509-515.

9. Pauly D, Christensen V, Guénette $S$, et al. Towards sustainability in world fisheries. Nature 2002; 418:689-695.

10. Food and Agriculture Organization. Ethical issues in fisheries. Rome: FAO, 2005.

11. Ashley PJ. Fish welfare: Current issues in aquaculture. Appl Anim Behav Sci 2007; 104:199-235.

12. Hisey SL, Berend KR. Fit to Fish. How to Tackle Angling Injuries. Oregon: Frank Amato Publications, 2005.

13. Feitsma H, Cuppen E. Zebrafish as a cancer model. Mol Cancer Res 2008; 6:685-694.

14. Islam MN, Islam MS. Human-animal relationship: Understanding animal rights in the Islamic ecological paradigm. J Religions Ideologies 2015; 14:96-126.

15. Cushing DH. The Provident Sea. Cambridge: Cambridge University Press, 1987.

16. FAO fisheries statistics software. FishstateJ. Rome: FAO, 2016.

17. Alverson DL, Dunlop K. Status of world marine fish stocks. Washington: Fisheries University of Washington, 1998.

18. Rahman MM, Verdegem MCJ. Multi-species fishpond and nutrients balance. In: ven der Zijpp AJ, Verreth AJA, Tri LQ, ven Mensvoort MEF, Bosma RH, Beveridge MCM, eds. Fishponds in farming systems. Wageningen: Wageningen Academic Publishers, 2007:79-88.

19. Rahman MM. Effects of co-cultured common carp on nutrients and food web dynamics in rohu aquaculture ponds. Aquacult Environ Interact 2015; 6:223-232.

20. Antony PJ, Rahman MM, Rajkumar M, Kamaruzzaman Y, Khan SA. Relative growth of Harpiosquilla raphidea (Fabricius, 1798) (Crustacea: Stomatopoda) male and female populations. Sains Malays 2014; 43:1305-1310.

21. Pauly D, Palomares ML, Froese R, et al. Fishing down Canadian aquatic food webs. Can J Fish Aquat Sci 2001; 58:51-62.

22. Amira FS, Rahman MM, Kamaruzzaman $\mathrm{Y}$, et al. Relative abundance and growth of male and female Nemipterus furcosus population. Sains Malays 2016; 45:79-86.

23. Naylor RL, Goldburg RJ, Primavera J, et al. Effect of aquaculture on world fish supplies. Nature 2000; 405:1017-1024.

24. Siddik MAB, Rahman MM, Anh NTN, Nevejan N, Bossierri P. Replacement of fishmeal by increasing levels of gut weed protein blends in diets for Nile tilapia, Oreochromis niloticus (Linnaeus) fry. J Appl Aquacult 2016; 27:113123.

25. Wu B, Xia S, Rahman MM, et al. Substituting seaweed with corn leaf in diet of sea cucumber (Apostichopus japonicus): effects on growth, feed conversion ratio and feed digestibility. Aquaculture 2015; 444:88-92.

26. Food and Agriculture Organization. The State of World Fisheries and Aquaculture. Rome: FAO, 2012.

27. Grigorakis K. Ethical Issues in Aquaculture Production. J Agr Environ Ethic 2010; 23:345370.

28. Innal D, Erk'akan F. Effects of exotic and translocated fish species in the inland waters of Turkey. Rev Fish Biol Fisher 2006; 16:39-50.

29. Gjedrem T, Baranski M. Selective Breeding in Aquaculture: an Introduction. London: Springer, 2009.

30. Harvell CD, Kim K, Burkholder JM, et al. Emerging marine diseases: climate links and anthropogenic factors. Science 1999; 285:1505 $-1510$.

31. Hall POJ, Holby O, Kollberg S, et al. Chemical fluxes and mass balances in a marine fish cage farm. IV. Nitrogen. Mar Ecol Prog Ser 1992; 89:81-91.

32. Rahman MM, Verdegem MCJ, Nagelkerke LAJ, et al. Effects of common carp Cyprinus carpio (L.) and feed addition in rohu Labeo rohita (Hamilton) ponds on nutrient partitioning among fish, plankton and benthos. Aquacult Res 2008; 39:85-95.

33. Noroi G, Glud RN, Gaard E, Simonsen K. Environmental impacts of coastal fish farming: carbon and nitrogen budgets for trout farming in Kaldbaksfjørður (Faroe Islands). MEPS 2011; 431:223-241.

34. Rahman MM, Kadowaki S, Balcombe SR, Wahab MA. Common carp (Cyprinus carpio L.) alter their feeding niche in response to changing food resources: direct observations in simulated ponds. Ecol Res 2010; 25:303-309.

35. Bullerjahn GS, McKay RM, Davis TW, et al. Global solutions to regional problems: Collecting global expertise to address the problem of harmful cyanobacterial blooms. A Lake Erie case study. Harmful Algae 2016; 54:223-238.

36. Rahman MM, Verdegem MCJ, Wahab MA. Effects of tilapia (Oreochromis nilotica L.) addition and artificial feeding on water quality, and fish growth and production in rohu-common carp bi-culture ponds. Aquacult Res 2008; 39:1579-1587. 
37. Iwama GK, Pickering AD, Sumpter JP, Schreck $\mathrm{CB}$. Fish stress and health in aquaculture. Cambridge: Cambridge University Press, 1997.

38. Khatune-Jannat M, Rahman MM, Bashar MA, et al. Effects of stocking density on survival, growth and production of Thai climbing perch (Anabas testudineus) under fed ponds. Sains Malays 2012; 41:1205-1210.

39. Li M, Rahman MM, Wu B, Lin Y-C. Effects of dietary canthaxanthin on growth and body colour of blood parrot cichlid Amphilophus citrinellus $\times$ Paraneetroplus synspilus. Aquacult Int 2016; 25:705-713.

40. Ellis $T$, North B, Scott AP, et al. The relationships between stocking density and welfare in farmed rainbow trout. J Fish Biol 2002, 61:493-531.

41. Lines JA, Spence J. Safeguarding the welfare of farmed fish at harvest. Fish Physiol Biochem 2012; 38:153-162.

42. Mood A. Worse things happen at sea: the welfare of wild-caught fish. UK, 2010.

43. Rahman MM, Balcombe SR. Competitive interactions under experimental conditions affect diel feeding of two common aquaculture fish species (Labeo calbasu Hamilton, 1822 and Cirrhinus cirrhosus Bloch, 1795) of southern Asia. J Appl Ichthyol 2016; 33:146-151.

44. Rahman MM. Gonadosomatic index-based size at first sexual maturity of males and females of Amblygaster clupeoides (Bleeker, 1849) (Clupeidae) at the east coast of the Malaysian peninsular. J Appl Ichth 2016; 33:579-582.

45. Rahman MM, Meyer CG. Effects of food type on diel behaviours of common carp Cyprinus carpio L. in simulated aquaculture pond conditions. J Fish Biol 2009; 74:2269-2278.

46. Rahman MM, Hossain MY, Jo Q, et al. Ontogenetic shift in dietary preference and low dietary overlap in rohu (Labeo rohita) and common carp (Cyprinus carpio) in semiintensive polyculture ponds. Ichthyol Res 2009; 56:28-36.

47. Rajkumar M, Rahman MM, Reni Prabha A, Phukan B. Effect of cholymbi on growth, proximate composition, and digestive enzyme activity of fingerlings of long whiskered catfish, Mystus gulio (Actinopterygii: Siluriformes: Bagridae). Acta Ichthyol Piscat 2013; 43:15-20.

48. Rajkumar M, Rahman MM. Culture of the Calanoid Copepod, Acartia erythraea and Cyclopoid Copepod, Oithona brevicornis with Various Microalgal Diets. Sains Malays 2016; 45:615-620.

49. Peter S. All animals are equal. In: Regan T, Peter S, eds. Animal Rights and Human Obligations. New Jersey: Prentice Hall, 1989:148-162.

50. Bakar IA. Islamic Theological Teachings on Ecology. Int J Busin Soc Sci 2012; 3:222-226.

51. Ramadan T. Radical Reform: Islamic Ethics and Liberation. Oxford: Oxford University Press 2009.

52. Reyaz A 2012. Animal Welfare in Islam.
Available at: http://www.saglobalaffairs.com/ special-features/1323-animal-welfareinislam.pdf

53. Rizk RR. Islamic Environmental Ethics. J Islam Account Busin Res 2014; 5:194-204.

54. Badi JA 2002. Commentary of forty Hadiths of an Nawawi. Available at: http://

fortyhadith.iiu.edu.my

55. Sneddon LU. Ethics and welfare: Pain perception in fish. Bull Eur Ass Fish Pathol 2006; 26:6-10.

56. Blessing JJ, Marshall JC, Balcombe SR. Humane killing of fish for scientific research: a comparison of two methods. J Fish Biol 2010; 76:2571-2577. 